\title{
Din ve Birey (Batson, Schoenrade, Ventis)
}

\author{
Fazlı AKIŞ*
}

\author{
Din ve Birey \\ Batson, C. D., P. Schoenrade ve W. L. Ventis \\ çev. A. Kuşat ve A. Taştan \\ Kimlik Yay., Kayseri 2017, 508 sayfa
}

\section{$\S \S \S$}

Özgün adı, Religion and the Individual (A Social-Psychological Perspective) olan Din ve Birey adlı bu eser, Kayseri Erciyes Üniversitesi İlahiyat Fakültesi Öğretim Üyelerinden Prof. Dr. Abdulvahap TAŞTAN ile Doç. Dr. Ali KUŞAT tarafından tercüme edilmiş ve Nisan 2017'de Kimlik Yayınlarından okuyucuya ulaşmıştır.

Bu eserin odak noktasını "bireysel dindarlık" oluşturmaktadır. Dolayısıyla bir sosyal psikoloji kitabı olan bu eser aslında Batson ve Ventis'in Dini Tecrübe (The Religious Experience, Oxford University Press, 1982) adlı kitabının bir revizyonu, açıklaması, güncellenmesi ve genişletilmiş şeklidir.

Dört bölüm ve on bir alt başlıktan oluşan bu eser, okuyucusuna dini davranış ve tecrübe alanında yapılmış ampirik sosyal psikolojik araştırmaların bir sentezini ve incelemesini sunmaktadır. Günümüzde oldukça çeşitli görünümler altında ortaya çıkan dini tecrübe olgusu araç, amaç ve arayış olarak üç boyutlu dindarlık modeliyle açıklanmaya çalışırken oldukça tutarlı, kapsamıı, tarafsız, ayrıntılı ve dengeli bir yaklaşım sergilenmiştir. Bu yönüyle eser, özellikle din psikolojisi alanına ilgi duyanların mutlaka okuması gereken bir kitap olarak görülebilir. Ancak dini tecrübenin toplumsal boyutuyla ilgilenen ve din, ruh sağlığı ve gruplar arası ilişkileri anlamaya çalışan sosyologlar için

* Çukurova Üniversitesi Sosyal Bilimler Enstitüsü Felsefe ve Din Bilimleri Anabilim Dalı Yüksek Lisans Öğrencisi, e-posta: fazliakis@hotmail.com 
oldukça değerli ve yararlı bir çalışmadır. Böyle bir çalışmanın dilimize kazandırılması oldukça önemlidir.

Kadim tarihin birbiriyle ilişkili olan ve birbirinden bağımsız olmayan iki unsuru olan 'din' ve 'birey', birbirlerinden çok farklı manaları haiz olsalar da bir bütünün ayrılmaz iki parçası gibidirler. Tarihin hiçbir evresinde dini değerlerden ve birtakım kutsal unsurların varlığından bîhaber birey ve toplum varlığı görülmemiştir. Çalışmada din ile birey ilişkilerinden örnekle tanımlamalar yapılmış ve bu tanımlardan din olgusuna ulaşılmaya çalışılmıştır. Dini inanç, değer ve ilkelerin varlığından ziyade bireyin hayatındaki fonksiyonları ve sonuçsal etkileri konu edilmiştir (s.3). Bireysel dinin açık ve anlaşılır sosyal psikolojik resmini oluşturmaya çalışılmış; bireysel din incelenirken dinin tanımından, çeşitlilik ve işlevselliğinden örnekler sunulmuş, dinin karmaşık yapısından veya öyle algılanışından bahsedilmiştir (s.4-6). Ayrıca dinin birey için tutsaklık mı özgürlük mü olduğu tartışma konusu olmuş, bireyin baş edemediği sorunlar karşısında varoluşsal tepkiyle çözüm kaynağını ilahi iradeye tevcih eylediği görülmüştür. Bireysel dinin boyutlarını açıklarken yaşanılan tecrübenin/dindarlığın neleri kapsadığına değinilmiştir. Buradaki temel neden, doğru ve yanlış din algılarından yola çıkılarak yapılan tanımlamalardır. Bu ayrım İslam'ın dindarlık biçimlerine atfettiği ihlas ve riya ile benzerliği, konunun tutarıılığını pekiştirmektedir. Nitekim Allport (1966:454), kiliseye menfaat ve çıkar için gidenleri bizatihi dini amaç için gidenlerden ayırmıştır.

Din-birey etkileşimini açıklarken, klasik yaklaşımlardan ve geçmiş uygulamalardan titizlikle istifade edilmiş, din psikolojisi ve din sosyolojisi literatüründen her bilgi ve yöntemi kullanma yerine, çalışmaya (din-birey analizine) doğrudan katkı sağlayan teknik ve yöntemlere yer verilmiştir. Yani geleneksel sosyoloji ve psikolojiden ziyade, doğrudan sosyal psikoloji literatüründen yararlanılmıştır.

Yazarların iddiasıyla, sosyal psikolojik alanında yapılan böyle bir çaışmada, kavramsal cümleler ve ampirik gözleme dayanan çıkarımlar okuyucunun -eğer bu alanda profesyonel bir okuyucu değilse- zihnini karıştırabilir. Çünkü bu kitapta yazarlar, sosyal psikoloji literatürüyle, dinin doğası, nihai sonuçları ve bireyin yaşamındaki etkisiyle ilgili okuyucuya koskoca bir kavram haritası sunmaktadır. Bu bağlamda kitabın üç yazarının da Amerikan Protestanlığı dini geleneği içerisinde yetişmiş olduğu, dolayısıyla okuyucuya sunulmak istenen dinin belli sosyal psikolojik analizinin sınırlılıkları olmakla birlikte batılı din anlayışı özellikte de ABD'nin Hristiyan kültür ortamında geliştirilmiş olduğu gözden uzak tutulmamalıdır.

Okuyucu kitlesini; (1) dinle ilgilenen herhangi biri, (2) öğrenciler, özellikle sosyal psikoloji, din psikolojisi ve din sosyolojisi öğrencileri ve (3) profesyonel meslektaşlar olarak üç kategoride (s.ii) ele alan yazarlar, çalışmanın ve 
kullanılan metodun oldukça açık, anlaşılır olmasına ve fazla detaya inmeden temel noktalarına değindiklerine vurgu yapmışlardır. Araştırmadan çıkan sonuçların, yalnızca öğrenciler veya bu alandaki uzman kişiler değil, din ile ilgilenen herhangi bir kimse tarafından da rahatlıkla anlaşılabileceğine değinilmiştir. Bu da eserin dilinin anlaşılır ve akıcı olduğunu göstermektedir.

Kanaatimizce, akademik analizler ve tabirler dışında çoğunlukla bu hususta başarılı olunmuş gibi. Çünkü tercüme yoluyla okuyucuya aktarılan bir yapıtta, kavramsal ifadeler, kalıp yargılar ve dilin deyim-atasözleri, özel isimler tercüme kalıplarına sığmayan özel anlamlar içerebiliyor. Yazarın yukarıda aktardığımız açık ve rahat bilgi sunumu ile mütercimlerin çeviride kullandıkları akademik dildeki başarıları, kitabın okunmasında ve anlaşılmasında çok büyük katkılar sağlamış, çoğu çeviride var olan devrik ve kopuk cümle yapısının olmayışı ayrı bir zenginlik olmuştur. Bu sebeple mütercimler özel bir teşekkür hak etmektedir.

Sosyal psikolojik yönüyle birey ve din etkileşimi inceleyen bu çalışmada din, sosyal psikolojik anlamda "ne yaparsak yapalım, varoluşsal sorunlarla baş edebilme yoludur" diye tanımlanmıştır (s.57). Bu nedenle bu kitabın içerik oluşumunda bireyin dindarlık ve dünyevilik algısı, yaşantısı muhtelif detaylarla dillendirilmekte, eserin ana temasını varoluşsal sorunlar ve dindarlığın temel boyutları oluşturmaktadır. Hayatın anlamı, gayesi nedir? Başkaları ile ilişkinin sınırııkları nelerdir? Şahsi kusurlarla başa çıkma yolları nelerdir? Ölüm gerçeği ile nasıl baş edilebilir? gibi sosyal psikolojinin odaklanması gereken varoluşsal sorunlara cevaplar aranmıştır. Bu cevapları ararken sosyal psikoloji, işaret ve semptomları doğru okuyarak kendiliğinden gizemli, gözlenemeyen ve derin kişisel tecrübelerinin varlığını çözmede ampirik bir kriter temin eder. Fenomenolojik yaklaşım dini davranışa ve dini tecrübeye yoğunlaşırken, ampirik yöntem de açık bir şekilde doğrulanabilir güvenlikte olan bilimsel yöntemleri kullanır (s.23).

Eserde kişisel dini tutum ve davranışlar büyük ölçüde toplumsal etkinin ürünü olarak ele alınmıştır. Bunun yanında bireylerin dinsel anlamda tutum ve davranışlarını belirlemede sosyal etkinin yanı sıra sosyal arka plan da oldukça etkili olduğu dile getirilmiştir. Bandura'ya (1977) atfen bireysel din, bireyin dinini sosyal öğrenme süreci yoluyla edindiği anlayışına (Sosyal Öğrenme Teorisine) dayandırıır (s.61). Bu tür yaklaşımlar bireysel dindarlığın sadece psikolojik değil, aynı zamanda sosyolojik açıdan da ele alındığının bir göstergesidir.

Gelişim psikologlarına göre insan bedeni büyüyüp geliştikçe yeni tecrübeler edinir. Fiziksel gelişimin her evresi ve bu evrelerde kazandığı tecrübeler bireysel din için hayati öneme sahip özellikler içerir. Ahlaki düşünce de dinin aslî bir parçasıdır. Fiziki ve zihinsel açıdan olgunlaşmayla ahlaki düşün- 
ce de gelişir ve değişir. Kohlberg (1969) ahlaki gelişimi Piaget'in dört aşamalı bilişsel analizini (s.66-7) genişleterek altı aşamada ele almıştır. Ona göre bu altı aşama evrenseldir ve hiyerarşik bir şekilde birbirini takip ederek birbirini tamamlar. İlaveten bu eserde, Kohlberg ve Piaget'in analizlerinin yanı sıra Erik Erikson'un (1950) psiko-sosyal gelişim temelli analizine de yer verilmiştir (s.80-1).

Kişisel dini tecrübe birçok formda ortaya çıkar. Edwin Starbuck'un (1899) birinci-doğuş dini dediği din, insanlar için olağanüstü bir şey olarak değil de, gündelik hayatta var olan şeylerin basit birer açıklaması olarak görülür. İkinci-doğuş dini ise, gündelik hayatın ötesine kişisel, etkileyici ve istisnai olaylar içerir. Mesela Malcom X, ırkçılık protestoları sonucunda ABD'de hapse atılınca orada ilk defa İslam ile karşılaştı. Sonra siyahi bir müslüman din görevlisi olarak gittiği Mekke'de yeni ve hayatını büyük ölçüde etkileyen içgörüler kazandı. Arkadaşlarına yazdığı mektupta, gördüğü ve tecrübe ettiği şeylerin düşüncelerini değiştirdiğini; farklı renk, ırk ve dilden insanlarla aynı Tanrıya ibadet ederek aynı tabaktan yemek yediklerini, su içtiklerini; siyahi müslümanlar arasında hissettiği samimiyeti beyaz müslümanlar arasında da hissettiğini ve bütün bunların sonucunda beyaz ırkın üstünlüğü yargısının boşa çıktığını belirtmiştir (s.100-1).

Günümüzde din incelemeleri oldukça popüler hale gelmiştir. Çeşitli bilim dalları konuyla ilgili incelemeler ve araştırmalar yapmaktadır. Söz gelimi, dinin ve dini tecrübenin psikolojik yönünü din psikolojisi, toplumsal yönünü din sosyolojisi incelemektedir. Ancak interdisipliner bir yaklaşımla her iki disiplininden de yararlanmak gerektiği düşüncesiyle din olgusuna psiko-sosyal veya sosyo-psikolojik yaklaşım denemeleri çoktandır yapılmaktaydı. Bu bağlamda eserin en önemli yanı, din psikolojisi ve din sosyolojisi gibi disiplinlerin yanı sıra "din sosyal psikolojisi" adlı yeni bir disiplinden söz etmesi ve bunu tartışmaya açmasıdır. Anlatım ve muhteviyat zenginliği itibariyle bu eserin din sosyal psikolojisi alanında yeni bir kapı aralayacağı dair bir beklenti söz konusudur. Sosyal psikolojisi alanında bir boşluğu doldurması beklenen bu eserin dilimize kazandırılması, din sosyolojisi ve sosyal psikoloji adına çok önemli bir kazanım olmuştur. Konuya ilgi duyanlara için son derece yararlı olacağı açıktır. 